\title{
A Study on Performance Evaluation of Select Central Public Sector Enterprises in India
}

\author{
N. Deepa \\ Assistant Professor, Department of Commerce, Sri Vasavi College, Erode - 638316, Tamil Nadu, India; \\ deepaprb@yahoo.com
}

\begin{abstract}
The Central Public Sector Enterprises in India are considered to be the powerful instrument of bringing socio-economic transformation in India. The contribution of Central Public Sector Enterprises towards GDP of India is highly remarkable. The industries under various sectors in the hold of Central Government are responsible for the development of the nation. Hence, this study is an attempt to evaluate the performance of select Maharatna Status Central Public Sector Enterprises using ratio analysis and also to examine the financial health by employing the Altman Z Score Model for the period of ten years from 2007-08 to 2016-17. It is found from the study that the sample companies are showing better performance in liquidity and financial solvency but BHEL shows poor performance in inventory management. The study also reveals that NTPC and SAIL are in distress zone.
\end{abstract}

Keywords: Financial Health, Liquidity and Performance Evaluation

\section{Introduction}

India is a country with agriculture as its primary occupation. The industrial sector has seen its tremendous growth with the establishment of Public Sector Enterprises. The government established Public Sector Enterprises (PSEs) with the main objective of accelerating economic growth, self sufficiency in production, stability in pricing policy and equilibrium in balance of payments for a long period. The PSEs in India operate at three levels of administration - Centre, State and Local government level. CPSEs contribute to both macro-economic objectives as well as to socio-economic objectives of the country and holds a pivotal market position in petroleum, power, steel, mining and transportation sectors.

The status of PSEs provides greater financial autonomy to become global giants. The government established the higher Maharatna status to those companies which raised its investment ceiling from Rs. 1000 crores to Rs. 5000 crores. The better performance of the Maharatna PSEs will contribute to employment generation, Gross Domestic
Product, National Domestic Product, increase in foreign exchange earnings and profitability. In this aspect, the present study focuses on the evaluation of performance of the select Central Public Sector Enterprises in India.

\section{Statement of the Problem}

The Public Sector Units are established to serve various macroeconomic objectives of India. Though the Central Public Sector Units (CPSUs) have reformed the business and bench marked their performance and marching towards sustainability, many CPSUs are still facing several problems such as poor performance, continuous losses, ineffective governance, high operating cost, low rate of return on investment etc. These problems are forcing them to march towards financial distress. The problem of poor financial performance always leads to huge socioeconomic losses to the economy as a whole. One of the most important threats for any business today is insolvency due to which, not only owners but also other users of 
financial statements are affected. Hence, an early warning of probable failure will enable the management and others to take preventive action. Therefore, this study makes an attempt to analyze the financial performance and also to predict the financial health of select Central Public Sector Enterprises in India.

\section{Review of Literature}

Krishna Reddy ${ }^{1}$ suggested that the PSE's performance was better in all the select indicators in the post-liberalization regime compared to pre-liberalization period. Prashant Kumar and Sumita Sinku ${ }^{2}$ found that Steel Authority of India (SAIL) had good profit earning capacity, liquid position, long-term solvency position and low level of bankruptcy during the study period. Vishal Patidar and Nilesh P Movalia ${ }^{-}$evaluated the efficiency of National Thermal Power Corporation (NTPC) and National Hydro Power Corporation (NHPC). The study revealed that Z-score of NHPC is below 1.65 from 2010-2011 to 2014-2015 which showed a weak financial position whereas NTPC was in too healthy zone and successful in its financial performance. Jain $\mathrm{VK}^{4}$ examined the performance of select steel companies for the period from 2000-01 to 2016-17 using financial ratios and found that liquid and profit earning capacity of the two sample companies were quite good.

\section{Objectives of the Study}

$>$ To analyze the overall financial performance of select Maharatna Status Central Public Sector Enterprises.

$>$ To forecast the Financial Health and Viability of the select Maharatna Status Central Public Sector Enterprises.

\section{Research Methodology}

The Central Public Sector Enterprises are the companies which has $51 \%$ or more of direct holding by the Central Government or other CPSUs. As on $31^{\text {st }}$ March 2017, there were 331 CPSUs (excluding insurance companies). Of these, 74 undertakings were yet to commence commercial operations. The existing 257 Central Public Sector Enterprises are classified as Maharatna, Navratna and Miniratna Status based on its level of investment. By adopting Judgement Sampling Technique, all the 7 CPEs categorized under Maharatna status are considered for the study which includes Bharat Heavy Electricals Limited (BHEL), Coal India Limited (CIL), Gas Authority of India Limited (GAIL), Indian Oil Corporation Limited (IOCL), National Thermal Power Corporation Limited (NTPC), Oil and Natural Gas Corporation (ONGC), Steel Authority of India Limited (SAIL) ${ }^{5}$. The study is based entirely on secondary data which is collected and compiled from the Annual Reports of the select companies for 10 years from 2007-08 to 2016-17. The collected data are tabulated and analyzed by using ratio analysis along with suitable descriptive statistics to know the financial performance and Z-score analysis is also used for analyzing the financial health of the select Maharatna status Central Public Sector Enterprises.

\section{Analysis and Discussion}

\subsection{Financial Performance of Select Central Public Sector Enterprises}

The financial performance of the select Maharatna status Central Public Sector Enterprises are examined by using:

- Current Ratio

- Debt-equity Ratio

- Net Profit Ratio

- Inventory Turnover Ratio

- Return on Total Assets Ratio

\subsubsection{Current Ratio}

The current ratio compares the firm's current assets and current liabilities. It is an indication of firm's liquid position. The ideal ratio is $2: 1$ and the companies with larger amount of current assets will be able to pay off its current liabilities more easily when they become due. The analysis of current ratio of select CPSEs during the study period is presented in Table 1.

Table 1. Current Ratio of Select Central Public Sector Enterprises in India

\begin{tabular}{|c|c|c|c|c|c|c|c|}
\hline \multicolumn{1}{|c|}{ (Ratio in Times) } \\
\hline Year & NTPC & ONGC & SAIL & BHEL & IOCL & GAIL & CIL \\
\hline $2007-08$ & 2.36 & 0.36 & 1.95 & 1.32 & 0.94 & 1.71 & 2.75 \\
\hline $2008-09$ & 2.89 & 0.30 & 1.83 & 1.30 & 0.72 & 1.50 & 3.02 \\
\hline $2009-10$ & 2.86 & 0.29 & 1.89 & 1.32 & 0.86 & 1.32 & 3.22 \\
\hline $2010-11$ & 2.57 & 0.78 & 1.51 & 1.73 & 1.01 & 1.06 & 2.60 \\
\hline
\end{tabular}




\begin{tabular}{|l|c|c|c|c|c|c|c|}
\hline \multicolumn{10}{c}{ (Ratio in Times) } \\
\hline Year & NTPC & ONGC & SAIL & BHEL & IOCL & GAIL & CIL \\
\hline $2011-12$ & 2.25 & 1.02 & 1.52 & 1.69 & 1.00 & 0.92 & 2.68 \\
\hline $2012-13$ & 1.82 & 0.84 & 1.22 & 1.65 & 1.03 & 1.00 & 2.28 \\
\hline $2013-14$ & 1.57 & 0.68 & 0.94 & 1.84 & 0.99 & 1.18 & 2.58 \\
\hline $2014-15$ & 1.22 & 0.64 & 0.82 & 1.96 & 0.99 & 1.06 & 4.72 \\
\hline $2015-16$ & 0.87 & 0.58 & 0.62 & 1.92 & 0.88 & 0.98 & 3.22 \\
\hline $2016-17$ & 0.74 & 0.54 & 0.55 & 2.03 & 0.85 & 1.09 & 2.77 \\
\hline Mean & $\mathbf{1 . 9 1 5}$ & $\mathbf{0 . 6 0 3}$ & $\mathbf{1 . 2 8 5}$ & $\mathbf{1 . 6 7 6}$ & $\mathbf{0 . 9 2 7}$ & $\mathbf{1 . 1 8 2}$ & $\mathbf{2 . 9 8 4}$ \\
\hline S.D & $\mathbf{0 . 7 9 3}$ & $\mathbf{0 . 2 4 0}$ & $\mathbf{0 . 5 3 0}$ & $\mathbf{0 . 2 7 7}$ & $\mathbf{0 . 0 9 7}$ & $\mathbf{0 . 2 5 3}$ & $\mathbf{0 . 6 7 7}$ \\
\hline C.V (\%) & $\mathbf{4 1 . 4 3 5}$ & $\mathbf{3 9 . 9 3 9}$ & $\mathbf{4 1 . 2 8 5}$ & $\mathbf{1 6 . 5 3 3}$ & $\mathbf{1 0 . 5 7 0}$ & $\mathbf{2 1 . 4 7 2}$ & $\mathbf{2 2 . 6 9}$ \\
\hline ACGR (\%) & $\mathbf{1 6 . 2 1 2}$ & $\mathbf{- 6 . 7 9 7}$ & $\mathbf{1 6 . 2 0 7}$ & $\mathbf{- 5 . 1 5 9}$ & $\mathbf{- 0 . 7 0 7}$ & $\mathbf{4 . 7 9 2}$ & $\mathbf{- 1 . 3 4 9}$ \\
\hline
\end{tabular}

\section{Source: Computed}

Table 1 shows that average current ratio of CIL and NTPC are closer to the standard norm of 2:1. Hence, their liquidity position is satisfactory revealing their ability to meet their matured current obligations. In case of ONGC and IOCL, the current ratio is less than the standard norms which indicates that these two firms are not having enough current assets to meet its current obligations. The co-efficient of variation signifies that NTPC has the highest variation in current ratio during the study period.
The companies like NTPC, SAIL and GAIL show positive growth of current assets while the other firms show a negative growth.

\subsubsection{Debt-equity Ratio}

The debt-equity ratio reflects the relative claims of creditors and shareholders against the assets of a firm. The ideal debt-equity ratio is $1: 1$. Table 2 presents the debt-equity ratio of the select CPSEs during the study period.

Table 2. Debt-Equity Ratio of Select Central Public Sector Enterprises in India

(Ratio in Times)

\begin{tabular}{|l|c|c|c|c|c|c|c|}
\hline \multicolumn{1}{|c|}{ Year } & NTPC & ONGC & \multicolumn{1}{c|}{ SAIL } & BHEL & \multicolumn{1}{c|}{ IOCL } & \multicolumn{1}{c|}{ GAIL } & CIL \\
\hline $2007-08$ & 0.501 & 0.858 & 0.231 & 0.014 & 0.485 & 0.207 & 0.113 \\
\hline $2008-09$ & 0.585 & 0.862 & 0.298 & 0.016 & 0.569 & 0.181 & 0.117 \\
\hline $2009-10$ & 0.596 & 0.875 & 0.466 & 0.012 & 0.529 & 0.181 & 0.085 \\
\hline $2010-11$ & 0.645 & 0.705 & 0.4 & 0.702 & 0.417 & 0.203 & 0.165 \\
\hline $2011-12$ & 0.686 & 0.767 & 0.447 & 0.499 & 0.555 & 0.336 & 0.168 \\
\hline $2012-13$ & 0.722 & 0.754 & 0.504 & 0.116 & 0.633 & 0.474 & 0.164 \\
\hline $2013-14$ & 0.794 & 0.736 & 0.491 & 0.322 & 0.774 & 0.49 & 0.164 \\
\hline $2014-15$ & 1.039 & 0.77 & 0.491 & 0.358 & 0.81 & 0.473 & 0.187 \\
\hline $2015-16$ & 1.036 & 0.763 & 0.573 & 0.326 & 0.593 & 0.376 & 0.215 \\
\hline $2016-17$ & 1.055 & 0.782 & 0.672 & 0.395 & 0.511 & 0.255 & 0.263 \\
\hline MEAN & $\mathbf{0 . 7 9 6}$ & $\mathbf{0 . 7 8 7}$ & $\mathbf{0 . 4 5 7 5}$ & $\mathbf{0 . 2 7 6}$ & $\mathbf{0 . 5 8 8}$ & $\mathbf{0 . 3 1 8}$ & $\mathbf{0 . 1 6 4}$ \\
\hline S.D & $\mathbf{0 . 2 0 7}$ & $\mathbf{0 . 0 4 2}$ & $\mathbf{0 . 1 2 6}$ & $\mathbf{0 . 2 3 3}$ & $\mathbf{0 . 1 2 3}$ & $\mathbf{0 . 1 2 8}$ & $\mathbf{0 . 0 5 1}$ \\
\hline C.V(\%) & $\mathbf{2 6 . 0 3 5}$ & $\mathbf{5 . 3 9 2}$ & $\mathbf{2 7 . 6}$ & $\mathbf{8 4 . 2 8}$ & $\mathbf{2 0 . 9 3 9}$ & $\mathbf{4 0 . 3 5 4}$ & $\mathbf{3 1 . 3 4}$ \\
\hline ACGR(\%) & $\mathbf{- 8 . 2 2 1}$ & $\mathbf{1 . 3 5 2}$ & $\mathbf{- 8 . 7 9 1}$ & $\mathbf{- 3 2 . 2 9}$ & $\mathbf{- 2 . 9 1 2}$ & $\mathbf{- 8 . 5 7 1}$ & $\mathbf{- 9 . 1 1 0}$ \\
\hline
\end{tabular}

Source: Computed

Table 2 shows that the average debt-equity ratio of all the select PSEs is less than the standard norm of 1:1. From the analysis, it is found that the select Central Public Enterprises are not maintaining optimum level of debt and equity.
However, the select CPSEs have equity dominated capital structure. The co-efficient of variation signifies that the variation is high for BHEL. All the sample companies except ONGC record a negative growth of debt-equity ratio. 


\subsubsection{Net Profit Ratio}

Net profit margin indicates management's ability to operate the business not only to recover all the expenses of operating business but also to have a reasonable margin to the owners. Generally, higher ratio of net profit is better. The analysis relating to net profit of select CPSEs during the study period is presented in Table 3 .

Table 3. Net Profit Ratio of Select Central Public Sector Enterprises in India

\begin{tabular}{|c|c|c|c|c|c|c|c|}
\hline \multicolumn{1}{|c|}{ (Ratio in } \\
\hline Year & NTPC & ONGC & SAIL & BHEL & IOCL & GAIL & CIL \\
\hline $2007-08$ & 19.877 & 27.805 & 16.321 & 14.632 & 2.814 & 14.000 & 9.0276 \\
\hline $2008-09$ & 19.436 & 25.195 & 12.516 & 11.791 & 0.960 & 11.541 & 10.361 \\
\hline $2009-10$ & 18.720 & 27.829 & 15.330 & 12.973 & 3.793 & 12.373 & 8.434 \\
\hline $2010-11$ & 16.448 & 28.740 & 11.325 & 14.461 & 2.458 & 10.796 & 11.469 \\
\hline $2011-12$ & 14.762 & 33.162 & 7.945 & 14.906 & 1.131 & 8.925 & 19.393 \\
\hline $2012-13$ & 19.062 & 25.436 & 4.866 & 13.891 & 1.278 & 8.345 & 27.805 \\
\hline $2013-14$ & 15.107 & 26.569 & 4.995 & 9.015 & 1.618 & 7.507 & 47.759 \\
\hline $2014-15$ & 13.922 & 21.592 & 4.092 & 4.804 & 1.254 & 5.288 & 34.571 \\
\hline $2015-16$ & 14.378 & 20.572 & 9.165 & 2.723 & 3.311 & 4.388 & 98.734 \\
\hline $2016-17$ & 11.884 & 23.037 & 5.693 & 1.719 & 5.409 & 7.165 & 50.022 \\
\hline MEAN & $\mathbf{1 6 . 3 6}$ & $\mathbf{2 5 . 9 9 4}$ & $\mathbf{6 . 2 5 3}$ & $\mathbf{9 . 5 4 7}$ & $\mathbf{2 . 4 0 3}$ & $\mathbf{9 . 0 3 3}$ & $\mathbf{3 1 . 7 5 8}$ \\
\hline S.D & $\mathbf{2 . 7 6 3}$ & $\mathbf{3 . 7 1 7}$ & $\mathbf{8 . 4 3 4}$ & $\mathbf{6 . 2 2 7}$ & $\mathbf{1 . 4 4 7}$ & $\mathbf{3 . 1 1 1}$ & $\mathbf{2 8 . 2 4 9}$ \\
\hline C.V & $\mathbf{1 6 . 8 9 1}$ & $\mathbf{1 4 . 3 0 0}$ & $\mathbf{3 4 . 8 6 9}$ & $\mathbf{6 5 . 2 2 7}$ & $\mathbf{6 0 . 2 4 9}$ & $\mathbf{3 4 . 4 4 3}$ & $\mathbf{8 8 . 9 5 0}$ \\
\hline ACGR & $\mathbf{- 4 . 8 5 8}$ & $\mathbf{- 2 . 9 1 5}$ & $\mathbf{- 1 2 . 0 6 2}$ & $\mathbf{- 1 9 . 5 9 4}$ & $\mathbf{4 . 8 9 3}$ & $\mathbf{- 1 0 . 4 4 5}$ & $\mathbf{2 9 . 6 8 0}$ \\
\hline
\end{tabular}

\section{Source: Computed}

Table 3 reveals that the average net profit ratio of select CPSEs, except IOCL have earned better profit during the period of study. The co-efficient of variation indicates that BHEL has high variation. However, the annual compound growth rate shows a negative growth rate of net profit throughout the study period for all the select CPSEs except IOCL and CIL.

\subsubsection{Inventory Turnover Ratio}

It expresses the relationship between the cost of goods sold and average inventory at cost. The higher ratio indicates efficient management of inventory.

Table 4 presents the inventory turnover ratio of select CPSEs during the study period.

Table 4. Inventory Turnover Ratio of Select Central Public Sector Enterprises in India

(Ratio in Times)

\begin{tabular}{|c|c|l|l|l|l|l|l|}
\hline Year & NTPC & ONGC & SAIL & BHEL & IOCL & GAIL & CIL \\
\hline $2007-08$ & 13.86 & 17.26 & 5.83 & 3.41 & 7.99 & 31.61 & 26.04 \\
\hline $2008-09$ & 12.94 & 15.76 & 4.33 & 3.4 & 12.21 & 39.55 & 16.29 \\
\hline $2009-10$ & 13.85 & 12.88 & 4.5 & 3.6 & 7.4 & 39.56 & 16.86 \\
\hline $2010-11$ & 15.13 & 16.59 & 3.83 & 3.89 & 6.66 & 38.05 & 11.47 \\
\hline $2011-12$ & 16.76 & 14.81 & 3.37 & 3.57 & 7.01 & 28.45 & 22.47 \\
\hline $2012-13$ & 16.19 & 14.55 & 2.79 & 4.12 & 7.54 & 30.95 & 22.49 \\
\hline $2013-14$ & 13.4 & 14.26 & 3.07 & 3.99 & 7.31 & 25.51 & 7.88 \\
\hline $2014-15$ & 9.83 & 13.9 & 2.58 & 2.99 & 9.61 & 27.27 & 6.64 \\
\hline $2015-16$ & 9.8 & 13.89 & 2.66 & 2.77 & 8.96 & 29.75 & 1.09 \\
\hline $2016-17$ & 12.03 & 12.6 & 2.83 & 4 & 5.77 & 28.35 & 4.24 \\
\hline
\end{tabular}


(Ratio in Times)

\begin{tabular}{|l|r|c|c|c|r|r|r|}
\hline \multicolumn{1}{|c|}{ Year } & NTPC & ONGC & SAIL & BHEL & IOCL & \multicolumn{1}{c|}{ GAIL } & CIL \\
\hline MEAN & 13.379 & 14.65 & 3.579 & 3.574 & 8.046 & 31.905 & 13.547 \\
\hline S.D & 2.363 & 1.508 & 1.047 & 0.446 & 1.826 & 5.243 & 8.564 \\
\hline C.V(\%) & 17.664 & 10.294 & 29.261 & 12.505 & 22.696 & 16.433 & 63.218 \\
\hline ACGR(\%) & 3.285 & 2.334 & 8.558 & 0.429 & 2.104 & 3.670 & 28.247 \\
\hline
\end{tabular}

Source: Computed

Table 4 discloses that the average inventory turnover ratio of NTPC, ONGC, GAIL and CIL is favorable. SAIL and BHEL proved their inefficiency in inventory management through its low inventory turnover. The co-efficient of variation shows the highest variation in inventory turnover ratio of CIL. The ratio has recorded a positive growth of inventory turnover for all the firms during the study period.

\subsubsection{Return on Total Assets}

Return on Total Assets (ROTA) measures the efficiency of a company to manage its assets to produce profits during a period. The higher ratio indicates more efficiency in managing the funds invested by creditors and owners in the total assets. The net income is calculated by adding interest and taxes with the income statement of the company (EBIT). The analysis of return on total asset ratio of the select CPSEs during the study period is revealed in Table 5.

Table 5. Return on Total Assets Ratio of Select Central Public Sector Enterprises in India

\begin{tabular}{|c|r|r|r|r|r|r|r|}
\hline \multicolumn{10}{|c|}{ (Ratio in } \\
\hline Year & NTPC & ONGC & SAIL & BHEL & IOCL & GAIL & CIL \\
\hline $2007-08$ & 7.85 & 13.1 & 18 & 8.14 & 5.94 & 11.95 & 12.44 \\
\hline $2008-09$ & 7.86 & 10.58 & 11.19 & 7.56 & 2.26 & 10.94 & 14.8 \\
\hline $2009-10$ & 7.75 & 9.97 & 9.72 & 8.87 & 6.99 & 10.38 & 15.77 \\
\hline $2010-11$ & 7.23 & 12.78 & 6.44 & 10.14 & 4.28 & 11.12 & 16.96 \\
\hline $2011-12$ & 6.54 & 14.62 & 4.82 & 10.54 & 1.88 & 9.34 & 26.26 \\
\hline $2012-13$ & 7.83 & 11.74 & 2.57 & 9.43 & 2.23 & 9 & 28.77 \\
\hline $2013-14$ & 6.11 & 11.08 & 2.84 & 4.75 & 2.79 & 8.78 & 59.93 \\
\hline $2014-15$ & 5.22 & 8.52 & 2.1 & 2.07 & 2.39 & 5.74 & 60.42 \\
\hline $2015-16$ & 4.77 & 7.27 & 4 & 1.08 & 5.09 & 4.33 & 78.34 \\
\hline $2016-17$ & 3.96 & 7.23 & 2.65 & 0.8 & 7.37 & 6.22 & 76.78 \\
\hline MEAN & $\mathbf{6 . 5 1 2}$ & $\mathbf{1 0 . 6 8 9}$ & $\mathbf{6 . 4 3 3}$ & $\mathbf{6 . 3 3 8}$ & $\mathbf{4 . 1 2 2}$ & $\mathbf{8 . 7 8}$ & $\mathbf{3 9 . 0 4 7}$ \\
\hline S.D & $\mathbf{1 . 4 4 4}$ & $\mathbf{2 . 4 8 9}$ & $\mathbf{5 . 1 2 8}$ & $\mathbf{3 . 8 2 7}$ & $\mathbf{2 . 1 0 5}$ & $\mathbf{2 . 5 5 4}$ & $\mathbf{2 6 . 7 8 1}$ \\
\hline C.V & $\mathbf{2 2 . 1 7 7}$ & $\mathbf{2 3 . 2 9 1}$ & $\mathbf{7 9 . 7 1 4}$ & $\mathbf{6 0 . 3 9 6}$ & $\mathbf{5 1 . 0 7 3}$ & $\mathbf{2 9 . 0 8 9}$ & $\mathbf{6 8 . 5 8 7}$ \\
\hline ACGR & $\mathbf{7 . 5 1 4}$ & $\mathbf{5 . 8 6 8}$ & $\mathbf{2 3 . 7 7 1}$ & $\mathbf{3 0 . 6 8 9}$ & $\mathbf{- 0 . 6 9 2}$ & $\mathbf{1 0 . 2 3 1}$ & $\mathbf{- 2 0 . 8 7 8}$ \\
\hline
\end{tabular}

\section{Source: Computed}

It is seen from Table 5 that the average return on total assets is the highest in case of CIL and ONGC. The co-efficient of variation indicates that SAIL and CIL have high variation. The annual compound growth rate shows that IOCL and CIL have negative growth of return on total assets.

\subsection{Measurement of Financial Health}

To measure the financial health of the select CPSEs, Altman's Z-score analysis is used. Altman's Multiple Discriminant Analysis model is attempted to identify the cause of deteriorating performance of the firms. It is represented as:

$$
Z=1.2 \mathrm{X}_{1}+1.4 \mathrm{X}_{2}+3.3 \mathrm{X}_{3}+0.6 \mathrm{X}_{4}+1.0 \mathrm{X}_{5}
$$

Where,

$\mathrm{Z}=$ Discriminant score.

$\mathrm{X}_{1}$ - Ratio of working capital to total assets.

$\mathrm{X}_{2}$ - Ratio of retained earnings/total assets.

$\mathrm{X}_{3}$ - Ratio of earnings before interest and taxes to total assets.

$\mathrm{X}_{4}$ - Ratio of market value of equity to total liabilities.

$\mathrm{X}_{5}$ - Ratio of total sales to total assets. 
When the " $Z$ " score is below 1.8 , the unit is considered to be in distress/bankruptcy zone. If " $Z$ " score is between 1.8 and 2.99 , the firm is said to be in grey zone and has moderate probability for bankruptcy. If " $Z$ " score is above
2.99 , the unit is in safe zone and has negligible probability of bankruptcy $\underline{6,7}$.

The detailed analysis through Z-score is given in Table 6 for the select CPSEs during the study period.

Table 6. Financial Health of the Select CPSEs

\begin{tabular}{|c|l|l|l|l|l|l|l|}
\hline Year & NTPC & ONGC & SAIL & BHEL & IOC & GAIL & CIL \\
\hline $2007-08$ & 1.885 & 4.1562 & 3.3068 & 5.0082 & 9.5613 & 2.6361 & 3.5842 \\
\hline $2008-09$ & 1.7948 & 3.88 & 2.5734 & 4.8427 & 10.452 & 2.6721 & 3.3158 \\
\hline $2009-10$ & 1.8121 & 3.5034 & 2.0902 & 5.1009 & 8.3596 & 2.4383 & 3.9017 \\
\hline $2010-11$ & 1.7379 & 4.2501 & 1.8595 & 3.9099 & 8.4748 & 2.5883 & 2.4118 \\
\hline $2011-12$ & 1.6889 & 4.6676 & 1.8142 & 3.9817 & 8.3515 & 2.3352 & 2.3299 \\
\hline $2012-13$ & 1.6058 & 4.167 & 1.5157 & 8.3391 & 8.759 & 2.328 & 2.2076 \\
\hline $2013-14$ & 1.5008 & 3.8901 & 1.3339 & 6.431 & 8.2805 & 2.4227 & 2.4669 \\
\hline $2014-15$ & 1.253 & 5.5218 & 1.2131 & 5.8129 & 8.9165 & 2.1707 & 2.4023 \\
\hline $2015-16$ & 1.1495 & 3.4573 & 0.7195 & 7.8953 & 7.2543 & 2.082 & 2.037 \\
\hline $2016-17$ & 1.1467 & 3.0345 & 0.7053 & 9.0785 & 6.4384 & 2.2583 & 1.8016 \\
\hline Mean Score & $\mathbf{1 . 5 5 7 4}$ & $\mathbf{4 . 0 5 2 8}$ & $\mathbf{1 . 7 1 3 1}$ & $\mathbf{6 . 0 4 0 0 2}$ & $\mathbf{8 . 4 8 4 8}$ & $\mathbf{2 . 3 9 3 2}$ & $\mathbf{2 . 6 4 5 9}$ \\
\hline
\end{tabular}

Source: Computed

Table 6 shows that the financial health of IOC, BHEL and ONGC are more satisfactory since their Z-score values are above '2.99' which keeps the companies in safe zone in all the years of the study period. The $\mathrm{Z}$ score value of GAIL and CIL indicates that the firms' financial viability is considered to be in grey zone and has moderate probability of bankruptcy. Further, NTPC and SAIL are in distress zone from 2007-08 to 2016-17 and has high probability of financial bankruptcy.

\section{Suggestions}

The following suggestions have been made based on the findings of the study:

$>$ The strategies followed by the successful Central Public Sector Enterprises could be identified and followed by other companies for making them turn around and survive in this competitive environment.

> Public undertakings which are in distress zone and are unlikely to be turned around must be considered by the Board for Industrial and Financial Reconstruction (BIFR) or other similar high level institutions without affecting the interest of the workers for the formulation of revival/rehabilitation scheme.

$>$ The decrease in profits of SAIL and IOC is due to increasing costs and decreasing sales. Therefore, these companies must increase its sales volume by decreasing the costs and in turn should increase the profits and improve the profitability position.

\section{Conclusion}

The present study revealed that out of the CPSEs taken for the study, IOCL and CIL are very poor in generating the returns on the total assets and all the sample firms are showing better performance in maintaining their liquidity and financial solvency. The Altman Z-score results revealed that the companies like GAIL and CIL were in grey zone and NTPC and SAIL were in distress zone. The CPSEs are having very crucial role in the economic development and hence, the failure of any CPSE may affect the socio economic balance of the country. Thus, the management of these companies must consider it as a warning signal to sensitize the development of the CPSEs.

\section{References}

1. Reddy K. Performance of PSEs in India: Pre and Post Liberalization Scenario. 2011 Aug. http://www.researchgate.net

2. Kumar P, Sinku S. Analysis of financial health of Steel Authority of India Limited. Journal of International Institute for Science, Technology and Education. 2014; 4(12):38-47. 
3. Patidar V, Movalia NP. An empirical study on financial health of NTPC and NHPC. Pacific Business Review International. 2016; 8(9):15-22.

4. Jain VK. Comparative study of performance analysis of SAIL and TSL. KAAV International Journal of Economics, Commerce and Business Management. 2018; 5(1):499-504.
5. Available from https://dipam.gov.in

6. Available from https://www.wallstreetmojo.com

7. Apoorva DV. Application of Altman Z-score model on selected indian companies to predict bankruptcy. International Journal of Business and Management Invention. 2019; 8(1):77-82. 